\title{
Study protocol of KLIMOP: a cohort study on the wellbeing of older cancer patients in Belgium and the Netherlands
}

Laura Deckx ${ }^{1 *}$, Doris van Abbema ${ }^{2}$, Katherine Nelissen ${ }^{3}$, Liesbeth Daniels ${ }^{1}$, Piet Stinissen ${ }^{3}$, Paul Bulens $^{4}$, Loes Linsen ${ }^{5}$, Jean-Luc Rummens ${ }^{3,5}$, Geert Robaeys ${ }^{3,6}$, Eric T de Jonge ${ }^{7}$, Bert Houben ${ }^{8}$, Karin Pat ${ }^{9}$, Daan Walgraeve ${ }^{10}$, Luc Spaas ${ }^{11}$, Jolanda Verheezen ${ }^{12}$, Thessa Verniest ${ }^{13}$, Alexander Goegebuer ${ }^{14}$, Hans Wildiers ${ }^{15}$, Franchette van den Berkmortel ${ }^{16}$, Vivianne C Tjan-Heijnen ${ }^{2}$, Frank Buntinx ${ }^{1,17}$ and Marjan van den Akker ${ }^{1,17}$

\begin{abstract}
Background: Cancer is mainly a disease of older patients. In older cancer patients, additional endpoints such as quality of survival and daily functioning might be considered equally relevant as overall or disease free survival. However, these factors have been understudied using prospective designs focussing on older cancer patients. Therefore, this study will focus on the impact of cancer, ageing, and their interaction on the long-term wellbeing of older cancer patients.

Methods/Design: This study is an observational cohort study. We aim to recruit 720 cancer patients above 70 years with a new diagnosis of breast, prostate, lung or gastrointestinal cancer and two control groups: one control group of 720 patients above 70 years without a previous diagnosis of cancer and one control group of 720 cancer patients between 50 - 69 years newly diagnosed with breast, prostate, lung or gastrointestinal cancer. Data collection will take place at inclusion, after six months, after one year and every subsequent year until death or end of the study. Data will be collected through personal interviews (consisting of socio-demographic information, general health information, a comprehensive geriatric assessment, quality of life, health locus of control and a loneliness scale), a handgrip test, assessment of medical records, two buccal swabs and a blood sample from cancer patients (at baseline). As an annex study, caregivers of the participants will be recruited as well. Data collection for caregivers will consist of a self-administered questionnaire examining depression, coping, and burden.

Discussion: This extensive data collection will increase insight on how wellbeing of older cancer patients is affected by cancer (diagnosis and treatment), ageing, and their interaction. Results may provide new insights, which might contribute to the improvement of care for older cancer patients.
\end{abstract}

\section{Background}

To a large extent, cancer is a disease of older people [1] and the number of older cancer patients will continue to increase [2]. Older patients have been under-represented in clinical trials [3], which has resulted in a paucity of evidence-based guidelines for treatment of older cancer patients [4]. Over the past decades progress has

\footnotetext{
* Correspondence: Laura.deckx@med.kuleuven.be

'Department of General Practice, Katholieke Universiteit Leuven,

Kapucijnenvoer 33, bus 7001, 3000 Leuven, Belgium

Full list of author information is available at the end of the article
}

been made in the field of geriatric oncology, nevertheless gaps remain [5].

One gap is the limited knowledge on the specific impact of cancer diagnosis and treatment on wellbeing or quality of survival of older cancer patients. Nevertheless, "prolongation of active life expectancy" or "quality of survival" is besides prolongation of survival increasingly recognised as an important treatment goal [6].

The impact of cancer diagnosis and treatment highly depends on the age of the patient. The assessment of ageing however is not straightforward. Chronological age by itself is not sufficient to assess ageing [6].

\section{Biomed Central}

(c) 2011 Deckx et al; licensee BioMed Central Ltd. This is an Open Access article distributed under the terms of the Creative Commons Attribution License (http://creativecommons.org/licenses/by/2.0), which permits unrestricted use, distribution, and reproduction in any medium, provided the original work is properly cited. 
Currently, one's physiological age is best estimated by a comprehensive geriatric assessment (CGA) [7]. A CGA is a multidisciplinary evaluation of an older individual's functional status, comorbidity, cognition, psychological status, social support, nutritional status and review of the patient's medications [8]. Unfortunately, a CGA is very time consuming. Therefore, a two-step approach using screening instruments has been suggested [9]. Examples are the abbreviated comprehensive geriatric assessment (aCGA) [10], the Vulnerable Elders Survey (VES-13) [11], the Groningen Frailty Index (GFI) [12], and the G8 [13] which has been included in the EORTC minimal Dataset [14]. However, the predictive value of these shorter instruments remains to be demonstrated.

Next to the CGA, a person's true age can also be determined by its "molecular/biological" age. From this molecular point of view, telomere length has been described as a measure of ageing as it reflects the organism's age at a cellular level [15-17]. Several studies reported a relationship between telomere length, several age-sensitive measures, and mortality [18-21]. However, more data are required from longitudinal studies that assess the association between telomere length and ageing-related functional measures and the impact of cancer on these parameters.

Age associated changes are also displayed by the immune system, which tends to result in a decreased immune competence also known as "immunosenescence" [22-24]. Currently, several longitudinal studies focusing on the very elderly, have started to reveal immune signatures or biomarkers of immune ageing consisting not of a single parameter, but a cluster of parameters increasingly recognized as an "immune risk profile" or IRP [25-27]. These parameters (CD4/CD8 T cell ratio < 1 ; cytomegalovirus (CMV) seropositivity; low $\mathrm{B}$ cell numbers; poor $\mathrm{T}$ cell proliferative responses) might be associated with mortality and aspects of wellbeing in a geriatric population. Therefore, they might potentially be used to identify people at risk for adverse outcomes and consequently develop interventions to delay or postpone these adverse outcomes. However, until now it remains to be determined whether the cluster of immune parameters in the IRP have a predictive value under any other circumstances, for instance in elderly cancer patients. Therefore, we aim to determine whether the IRP and other inflammatory markers (Interleukin-6 (IL-6); Tumour necrosis factor- $\alpha$ (TNF- $\alpha$ ); Creactive protein (CRP)) are associated with wellbeing/ mortality in older cancer patients.

Besides patient related characteristics, the social network is a very important factor that influences the wellbeing of older cancer patients. Older cancer patients often rely on the presence of caregivers. Unfortunately, the tasks of caregivers sometimes result in negative consequences to the caregivers' emotional and physical health, which is referred to as caregiver distress [28]. From this perspective, it has been shown that caregivers of older cancer patients are at increased risk for depression, which might result as a consequence of the burden of providing care, but also as a result of inadequate coping mechanisms [29]. Furthermore, depression/distress among caregivers might also negatively affect the patients' wellbeing. Nevertheless, information regarding caregiver distress, burden and coping in relation with older cancer patient characteristics and stage of the illness is still scarce. A long-term follow-up of cancer patients and caregivers will allow us to find prognostic factors for caregiver distress and to give incentives for interventions. Therefore, we aim to determine the impact of patient characteristics (such as change in wellbeing, disease and treatment characteristics) and caregiver characteristics (such as coping strategy and perceived burden) on the occurrence of distress and depression among caregivers.

In conclusion, this study has three major goals: 1) To assess the impact of cancer, ageing and their interaction on subsequent wellbeing of older cancer patients; 2) To determine the association between different measures of ageing (age in life years, a CGA, its screening instruments, telomere length and immunological parameters) and evaluate their ability to predict wellbeing of older cancer patients; 3) To assess the impact of patient and caregiver characteristics on the occurrence of caregivers' distress.

\section{Methods/Design}

\section{Study design and study population}

KLIMOP (Dutch acronym for project on older cancer patients in Belgium and the Netherlands) is a Belgian and Dutch observational prospective cohort study on older cancer patients aged 70 years and above and two control groups; older patients aged 70 years and above without a previous diagnosis of cancer (control for cancer) and cancer patients between 50 - 69 years (control for ageing) (see Table 1). As an annex study, caregivers of participants will be included as well.

The study population will consist of Belgian and Dutch participants:

- Cases: 720 older persons ( $\geq 70$ years), with a primary diagnosis of breast, prostate, lung or gastrointestinal cancer. Due to different procedures in the Belgian and Dutch hospitals, prostate cancer patients will not be included in Belgium.

- Control group 1 (control for cancer): 720 older persons ( $\geq 70$ years), without a previous diagnosis of invasive cancer (except non-melanoma cancer of the skin). 
Table 1 Study design

\begin{tabular}{|c|c|c|c|c|c|}
\hline \multicolumn{6}{|c|}{ KLIMOP } \\
\hline \multicolumn{3}{|c|}{ Cohort - Belgium } & \multicolumn{3}{|c|}{ Cohort - The Netherlands } \\
\hline Cases & Control group 1 & Control group 2 & Cases & Control group 1 & Control group 2 \\
\hline $\begin{array}{l}360 \text { Breast, lung and } \\
\text { gastro-intestinal } \\
\text { cancer patients } \\
\text { ( } \geq 70 \text { years })\end{array}$ & $\begin{array}{l}360 \text { Patients without } \\
\text { a previous diagnosis } \\
\text { of cancer } \\
\text { ( } \geq 70 \text { years })\end{array}$ & $\begin{array}{l}360 \text { Breast, lung and } \\
\text { gastro-intestinal } \\
\text { cancer patients } \\
\text { (50 - } 69 \text { years) }\end{array}$ & $\begin{array}{l}360 \text { Breast, lung-, gastro- } \\
\text { intestinal and prostate } \\
\text { cancer patients } \\
\text { ( } \geq 70 \text { years })\end{array}$ & $\begin{array}{l}360 \text { Patients without } \\
\text { a previous diagnosis } \\
\text { of cancer } \\
\text { ( } \geq 70 \text { years })\end{array}$ & $\begin{array}{l}360 \text { Breast, lung, gastro- } \\
\text { intestinal and prostate } \\
\text { cancer patients } \\
\text { (50 - } 69 \text { years })\end{array}$ \\
\hline 180 Caregivers & 180 Caregivers & 180 Caregivers & 180 Caregivers & 180 Caregivers & 180 Caregivers \\
\hline
\end{tabular}

- Control group 2 (control for ageing): 720 persons between 50 and 69 years old, with a primary diagnosis of breast, prostate, lung or gastrointestinal cancer. Prostate cancer patients will not be included in Belgium.

The caregiver population will consist of the (potential) caregivers of participating patients. In this study a caregiver is defined as the person who (most often) cares for a needy participant in his or her direct environment, or is most likely to do so when a participant becomes needy. The caregiver is related (family, friends, neighbours, volunteer, ...) to the participant and is not a professional caregiver [30].

Details on the in- and exclusion criteria are listed in Table 2. Control patients who become cases (older patients who become cancer patients) will be considered control and case for the respective periods. Controls, aged 70 years or older who will be diagnosed with cancer, other than breast, prostate, lung or gastrointestinal cancer will drop out. If the patient indicates that there is no caregiver, this will be recorded. If the patient indicates at the first follow-up visit he/she has a caregiver, the caregiver will be included at the first follow-up visit.
If the caregiver changes during the study, patients will be asked to indicate the reason. No other caregiver will be recruited.

\section{Recruitment}

Up to date, cancer patients are recruited through five hospitals in Belgium (Jessa Ziekenhuis, Ziekenhuis OostLimburg, Regionaal Ziekenhuis Sint-Trudo, Regionaal Ziekenhuis Heilig Hart Leuven, Universitair Ziekenhuis Leuven) and two in the Netherlands (Maastricht University Medical Centre and Atrium Medical Centre Parkstad Heerlen). Older patients without cancer are recruited through general practitioners affiliated with the department of General Practice of the K.U.Leuven and Maastricht University Medical Centre.

\section{Study endpoints and data collection}

The primary endpoint of this study is wellbeing of older cancer patients in comparison with younger cancer patients and older patients without a previous diagnosis of cancer. As wellbeing is a very broad concept, we defined four domains that we considered the most important indicators of wellbeing: quality of life, depression, functional status, and comorbidity. The secondary

Table 2 In- and exclusion criteria

\begin{tabular}{|c|c|c|c|c|}
\hline & $\begin{array}{c}\text { Cases: } \\
\text { Cancer patients } \\
\geq 70 \text { years }\end{array}$ & $\begin{array}{l}\text { Control group } 1: \\
\text { Patients without } \\
\text { cancer } \geq 70 \text { years }\end{array}$ & $\begin{array}{c}\text { Control group 2: } \\
\text { Cancer patients } \\
50-69 \text { years }\end{array}$ & Caregivers \\
\hline \multicolumn{5}{|c|}{ Inclusion criteria } \\
\hline Consenting after being informed & $\sqrt{ }$ & $\sqrt{ }$ & $\sqrt{ }$ & $\sqrt{ }$ \\
\hline Aged 70 years and older & $\sqrt{ }$ & $\sqrt{ }$ & & \\
\hline Aged between 50 and 69 years & & & $\sqrt{ }$ & \\
\hline Life expectancy more than 6 months ${ }^{1}$ & $\sqrt{ }$ & $\sqrt{ }$ & $\sqrt{ }$ & \\
\hline Persons who have a thorough command of Dutch & $\sqrt{ }$ & $\sqrt{ }$ & $\sqrt{ }$ & \\
\hline Interview within three months after cancer diagnosis & $\sqrt{ }$ & & $\sqrt{ }$ & \\
\hline \multicolumn{5}{|c|}{ Exclusion criteria } \\
\hline Persons with a formal diagnosis of dementia & $\sqrt{ }$ & $\sqrt{ }$ & $\sqrt{ }$ & \\
\hline Persons with a previous diagnosis of invasive cancer ${ }^{2}$ & $\sqrt{ }$ & $\sqrt{ }$ & $\sqrt{ }$ & \\
\hline Persons too ill to participate ${ }^{1}$ & $\sqrt{ }$ & $\sqrt{ }$ & $\sqrt{ }$ & \\
\hline
\end{tabular}

${ }^{1}$ based on the judgment of the attending doctor

2 except non-melanoma cancer of the skin 
endpoint of this study is caregiver distress. Caregiver distress is defined as the perceived burden and the extent of depressive feelings.

The most important co-variables are ageing, patients' characteristics, and caregivers' characteristics. The different measures of ageing include age in life years, degree of frailty measured by a CGA, the aCGA, the VES-13, the GFI, the G8 and telomere length as a measure of cell ageing. In the future, immunological parameters like Interleukin- 6 , Tumour necrosis factor- $\alpha, C$ reactive protein, $\mathrm{CD} 4 / \mathrm{CD} 8 \mathrm{~T}$ cell ratio and/or others linked to immunosenescence will be included in a sample of the patients. Patients' characteristics are operationalised as personal characteristics (socio-demographic information, distress, coping strategy, and health locus of control), disease characteristics (type of cancer and TNM classification), and treatment characteristics (type of treatment, treatment completion, complications, hospitalizations and complaints during treatment). Caregivers' characteristics are operationalised by sociodemographic information and coping strategy.

Data collection will take place at inclusion, after six months of follow-up, after one year of follow-up and every subsequent year until death or end of the study (see Figure 1). For cancer patients and older patients without cancer, data will be collected through personal interviews (consisting of socio-demographic information, general health information, a comprehensive geriatric assessment, quality of life, health locus of control and a loneliness scale), a handgrip test, medical information (extracted from the medical record) and two buccal swabs. In Belgium, a baseline blood sample will be collected as well for all cancer patients. The baseline interview of cancer patients ( $\geq 70$ years and 50 - 69 years) will take place at the hospital, scheduled together with other appointments. The baseline interview of older patients without cancer will take place during home visits, as well as the follow-up interviews of both cancer and non-cancer patients. For caregivers, data will be collected through self-administered questionnaires, which are partially given to them by the patients and partially sent by mail. A stamped envelope will be enclosed. The content of the data collection is summarized in Table 3.

\section{Sample size calculation}

Sample size calculations were based on the primary objective of this study: to determine the impact of cancer diagnosis, ageing, and their interaction on subsequent wellbeing of older cancer patients. Separate instruments such as the GDS-15 measure the four domains that we considered the most important indicators of wellbeing. Therefore, the sample size was calculated for depression as a dichotomous endpoint. The prevalence of depression has been reported to be about $25 \%$ in older cancer patients [31], while the prevalence of depression among community-dwelling older noncancer patients is considerably lower $(<15 \%)$ [32]. However, higher and lower prevalences of depression have been reported as well. Therefore, we simulated a few sample size calculations with:

- differing prevalences of depression in the control group: ranging from $25 \%$ to $65 \%$

- a relative risk for disease (depression) in older cancer patients relative to controls of 1.5

- a power to reject the null hypothesis of $80 \%$

- a type I error probability of 0.05

- a ratio of cases versus controls of one

Assuming these specifications, the total needed sample size was estimated between 626 patients (assuming a prevalence of depression of $25 \%$ in the control group) and 100 (assuming a prevalence of depression of 65\% in the control group). In comparison with other studies on

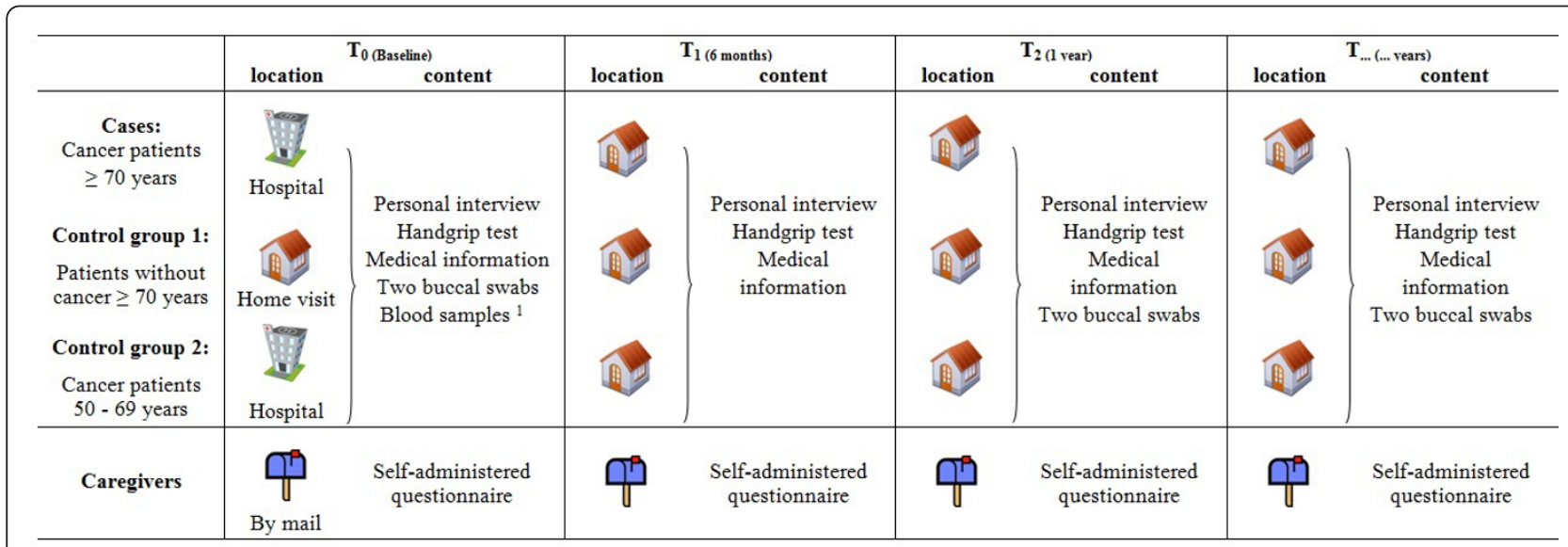

Figure 1 Study design. Only at baseline for Belgian cancer patients 
Table 3 Data collection

\begin{tabular}{|c|c|c|}
\hline Setting & & Data collection \\
\hline \multirow[t]{18}{*}{ Interview } & Ageing: CGA & \\
\hline & Functional & Activities of Daily Living (ADL): Barthel index $[41,42]$ \\
\hline & & Instrumental Activities of Daily Living (IADL): Lawton IADL scale [43] \\
\hline & & Handgrip strength: Hydraulic Jamar hand-held dynamometer \\
\hline & Polypharmacy & \\
\hline & Depression & 15-item Geriatric Depression Scale (GDS-15) [44] \\
\hline & Cognition & Mini Mental State Examination [45] \\
\hline & Nutritional status & $\begin{array}{l}\text { Participants will be asked whether they lost or gained weight in the past three months and } \\
\text { how much }{ }^{1}\end{array}$ \\
\hline & Social support & Questions considering the availability of a caregiver and professional care \\
\hline & & The loneliness scale [46] \\
\hline & $\begin{array}{l}\text { Ageing: Screening } \\
\text { instruments }\end{array}$ & Abbreviated CGA (aCGA) $[10,47]$ \\
\hline & & Vulnerable Elders Survey - 13 (VES-13) [11] \\
\hline & & Groningen Frailty Index (GFI) [12] \\
\hline & & G8 [13] which has been included in the EORTC minimal Dataset [14] \\
\hline & Quality of life & EORTC QLQ-C30 [48] \\
\hline & Distress & Distress Barometer (DB) [49] \\
\hline & Coping strategy & The Utrecht Coping List (UCL) [50] \\
\hline & $\begin{array}{l}\text { Opinion on health and } \\
\text { disease }\end{array}$ & Health Locus of control (HLoC) [51] \\
\hline \multirow[t]{9}{*}{ Medical record } & Survival & Date of death \\
\hline & Comorbidity & Charlston Comorbidity Index [52] + additional diseases ${ }^{2}$ \\
\hline & Disease characteristics & Data of cancer diagnosis, TNM classification, type of cancer \\
\hline & Treatment characteristics & Type of treatment \\
\hline & & Completion of therapy \\
\hline & & Complications \\
\hline & & Complaints (e.g. fatigue, pain) \\
\hline & & Hospitalizations \\
\hline & Medication & \\
\hline Buccal swabs & $\begin{array}{l}\text { Ageing: biological } \\
\text { parameters }\end{array}$ & Telomere length \\
\hline $\begin{array}{l}\text { Baseline blood } \\
\text { samples }^{3}\end{array}$ & & CD4/CD8 T cell ratio, CMV status, B cell number, IL-6, TNF- $\alpha$ CRP etc. \\
\hline \multirow[t]{4}{*}{$\begin{array}{l}\text { Questionnaire } \\
\text { caregivers }\end{array}$} & $\begin{array}{l}\text { Socio-demographic } \\
\text { information }\end{array}$ & \\
\hline & $\begin{array}{l}\text { Coping strategy of } \\
\text { caregiver }\end{array}$ & The Utrecht Coping List (UCL) [50] \\
\hline & Caregivers distress & 15-item Geriatric Depression scale (GDS15) [44] \\
\hline & & 12-item Zarit Burden Inventory (ZBI) [53] \\
\hline
\end{tabular}

\footnotetext{
${ }^{1}$ We decided that the extra information given by the Mini Nutritional Assessment would not outweigh the burden of 18 extra questions, including circumferences of the calf and upper arm.

${ }^{2}$ A limitation of the Charlston Comorbidity Index is that it does not take into account some disorders that might affect prognosis or evolution of quality of life in cancer patients. Therefore, some additional diseases will be registered as well (parkinsonism, blood transfusions, transplantations, thromboses, lung embolisms, a pacemaker, angina pectoris, a PCTA or a coronary bypass).

${ }^{3}$ Only for cancer patients in Belgium
}

older patients, we assumed a loss to follow-up and a yearly mortality rate of $10 \%$ among the two control groups and a loss-to follow-up and a yearly mortality rate of $20 \%$ among older cancer patients [33]. Finally, per country, a sample size of 360 cases (cancer patients aged 70 years and older), 360 controls (group 1: cancer patients between 50 - 69 years) and 360 controls (group 2: older patients without a previous diagnosis of cancer) per country was proposed, enabling within-country analyses. 
For caregivers, sample size was also calculated for depression as endpoint (instead of the combination of depression and burden). The prevalence of depression among caregivers ranges between 32 - 50\% [34]. Applying the same assumptions as for older cancer patients (relative risk of 1.5, a prevalence of depression of $25 \%$ $55 \%$ in the control group, a power of $80 \%$ and $\alpha 0.05$ ) the estimated sample size was similar $(626-100)$. As some patients will not have a caregiver, we expect it feasible to recruit about half of the caregivers of all participants. We expect to recruit about 550 caregivers per country.

\section{Ethics}

The study protocol was approved by the Ethical Committee of the K.U.Leuven and U.Z.Leuven (S52097 ML6279) (Belgium) and by the Medical Ethics Committee of the Maastricht University Medical Centre (NL31414.068.10) (the Netherlands). The study will be conducted in compliance with Good Clinical Practice guidelines Procedures (GCP), the principles of the Declaration of Helsinki (version October 2008) and the Belgian (law of 7 may 2004 concerning clinical trials with humans) and Dutch (Medical Research Involving Human Subjects Act and Personal Data Protection Act) laws.

\section{Data check and analysis}

All interviews and other data collection (e.g. medical information) are processed using software developed for this project. Data is entered directly in the database using this program. The quality of the data entry is verified by automated checking for erroneous or missing entries. Standard statistical analyses will be used for describing patient characteristics and comparing older cancer patients with the two control groups at baseline and during follow-up. When applicable more complex statistical methods such as multivariable logistic regression, survival analysis and methods to deal with repeated measurements will be used. In all analyses, two sided pvalues will be used at a significance level of 0.05 . In all future publications we will follow the STROBE criteria (Strengthening The Reporting of OBservational studies in Epidemiology) [35].

\section{Discussion}

To our knowledge, this is the first prospective cohort study that focuses on the wellbeing of older long-term cancer survivors. This is surprising as the number of older cancer patients is expected to increase dramatically due to the ageing of the population and advances in early detection and cancer treatments [2].

It has been repeatedly shown that older cancer patients are "less willing to compromise their quality of life for the potential of increased survival" [36]. Hence, in the geriatric oncology setting, traditional endpoints as survival might be less relevant. As suggested by Hurria \& Balducci, other endpoints such as the quality of survival may be considered equally relevant [37]. However, information on the quality of survival is lacking. Previous prospective studies that focused at aspects of quality of survival such as functional status and quality of life had only limited follow-up. For example, three prospective studies of Puts et al., Minisine et al., and Marinello et al. investigated the functional status in older cancer patients, but only until 6 months of follow-up [38-40]. Therefore, this study is unique as we aim to evaluate the quality of survival (here defined as wellbeing) of older cancer patients for an extended period. This study will provide insight in the evolution of wellbeing (in terms of Qol, depression, functional status and comorbidity) and the most important determinants among older cancer survivors in comparison with younger cancer survivors and older patients without a previous diagnosis of cancer. We expect to find associations between different measures of ageing and wellbeing of older cancer patients, which could help us identify people that need interventions to assure quality of survival and to tailor treatment for older cancer patients.

\section{Abbreviations}

aCGA: Abbreviated comprehensive geriatric assessment; ADL: Activities of daily living; CGA: Comprehensive geriatric assessment; CMV: cytomegalovirus; CRP: C reactive protein; DB: Distress barometer; EORTC Elderly MinsDS: EORCT Elderly Minimal Dataset; GDS-15: Geriatric depression scale; GFI: Groningen Frailty Index; HLoC: Health locus of control; IADL: Instrumental activities of daily living; IL-6: Interleukin 6; IRP: Immune Risk Profile; KLIMOP: Dutch acronym for project on older cancer patients in Belgium and the Netherlands; MMSE: Mini mental state examination; STROBE: Strengthening the reporting of observational studies in epidemiology; TNF-a: Tumour necrosis factor a; UCL: The Utrecht Coping List; VES-13: Vulnerable Elders Survey; ZBI: Zarit Burden Interview

\section{Acknowledgements and funding}

KLIMOP is funded by VLK, de Vlaamse Liga tegen Kanker and Interreg IV Grensregio Vlaanderen - Nederland. This study is only possible thanks to the participating patients and carers with their physicians and nurses. The authors would like to thank Ton Maessen for creating the database and the members of the Research Group on Older Cancer Patients for their help and support with patient recruitment. The members of the Research Group on Older Cancer Patients are: Dr. Mebis J (Department of Medical Oncology, Jessa Hospital), Dr. Vlasselaer J (Department of Gynaecology, Ziekenhuis Oost-Limburg), Dr. Van de Putte G (Department of Gynaecology, Ziekenhuis Oost-Limburg), Dr. Schobbens J (Department of Gynaecology, Ziekenhuis Oost-Limburg), Dr. Thomeer M (Department of Pulmonology, Ziekenhuis Oost-Limburg), Dr. Neuville B (Department of Gastroenterology, Ziekenhuis Oost-Limburg), Dr. Humblet E (Department of Gastroenterology, Ziekenhuis Oost-Limburg), Dr. Gevers A (Department of Gastroenterology, Ziekenhuis Oost-Limburg), Dr. Caenepeel P (Department of Gastroenterology, Ziekenhuis Oost-Limburg), Dr. Van der Speeten K (Department of Abdominal Surgery, Ziekenhuis Oost-Limburg), Dr. Staelens Y (Department of Oncology and Radiotherapy, Ziekenhuis Oost-Limburg), Dr. Brosens M (Department of Oncology and Radiotherapy, Jessa Hospital), Dr. Demuynck K (Department of Pulmonology Jessa Hospital), Kenis C (Department of General Medical Oncology, University Hospitals Leuven), Dr. Luyckx C (General practitioner), 
Dr. Truyen J (General practitioner), Dr. Lousbergh D (Department of General practice, K.U. Leuven), Dr. Smeets J (General practitioner), Dr. Bemelmans B (General practitioner), Dr. Hardy L (General practitioner), Dr. Vanschoenbeek J (General practitioner).

\section{Author details}

'Department of General Practice, Katholieke Universiteit Leuven, Kapucijnenvoer 33, bus 7001, 3000 Leuven, Belgium. ²Department of Medical Oncology, Maastricht University Medical Centre, GROW - School for Oncology and Developmental Biology, P.O. Box 5800, 6202 AZ Maastricht, The Netherlands. ${ }^{3}$ Faculty of Medicine, Hasselt University, Campus Diepenbeek, Agoralaan building A, 3590 Diepenbeek, Belgium. ${ }^{4}$ Limburgs Oncologisch Centrum, Stadsomvaart 11, 3500 Hasselt, Belgium. ${ }^{5}$ Biobank and Clinical Laboratory of Experimental Hematology, Jessa Hospital - campus Virga Jesse, Stadsomvaart 11, 3500 Hasselt, Belgium. ${ }^{6}$ Department of Gastroenterology, Ziekenhuis Oost-Limburg, Schiepse Bos 6, 3600 Genk, Belgium. ${ }^{7}$ Department of Gynaecology, Ziekenhuis Oost-Limburg, Schiepse Bos 6, 3600 Genk, Belgium. ${ }^{8}$ Department of Gastroenterology, Jessa Hospital - campus Virga Jesse, Stadsomvaart 11, 3500 Hasselt, Belgium. ${ }^{9}$ Department of Pulmonology, Jessa Hospital - campus Virga Jesse, Stadsomvaart 11, 3500 Hasselt, Belgium. ${ }^{10}$ Department of Gastroenterology, Jessa Hospital - campus Salvator, Salvatorstraat 20, 3500 Hasselt, Belgium. "'Department of Pulmonology, Jessa Hospital - campus Salvator, Salvatorstraat 20, 3500 Hasselt, Belgium. ${ }^{12}$ Department of Medical Oncology, Regionaal Ziekenhuis Sint-Trudo, Diestersteenweg 100, 3800 Sint-Truiden, Belgium. ${ }^{13}$ Department of Pulmonology, Regionaal Ziekenhuis Heilig Hart Leuven, Naamsestraat 105, 3000 Leuven, Belgium. ${ }^{14}$ Department of Gastroenterology, Regionaal Ziekenhuis Heilig Hart Leuven, Naamsestraat 105, 3000 Leuven, Belgium. ${ }^{15}$ Department of General Medical Oncology, University Hospitals Leuven, Campus Gasthuisberg, Herestraat 49, 3000 Leuven, Belgium. ${ }^{16}$ Department of Internal Medicine, Atrium Medical Centre Parkstad, Henri Dunantstraat 5, P.O, Box 4446, 6401 CX Heerlen, The Netherlands. ${ }^{17}$ Department of General Practice, Maastricht University, CAPHRI - School for Public Health and Primary Care, Peter Debeyeplein 1, P.O. Box 616, 6200 MD Maastricht, the Netherlands.

\section{Authors' contributions}

LDe drafted the manuscript and contributes to the data collection. DVA, $\mathrm{LDa}$, and $\mathrm{KN}$ contribute to the data collection. PS participated in the coordination of the study. PB contributed to the conception of the study and participated in the design and coordination of the study. LL and JLR contribute to the storage and processing of blood samples and buccal swabs. GR, ETdJ, BH, KP, DW, LS, JV, TV, AG, and HW coordinate the recruitment of cancer patients in the respective departments. FvdB and VCTH contributed to the design and the coordination of the study. FB contributed to the conception, the design, and coordination of the study. MvdA participated in the design and coordination of the study. All authors agreed with the final version of the manuscript and critically revised the manuscript.

\section{Competing interests}

The authors declare that they have no competing interests.

Received: 3 October 2011 Accepted: 25 October 2011 Published: 25 October 2011

\section{References}

1. Avis NE, Deimling GT: Cancer survivorship and aging. Cancer 2008, 113:3519-3529.

2. Ferlay J, Autier P, Boniol M, Heanue M, Colombet M, Boyle P: Estimates of the cancer incidence and mortality in Europe in 2006. Ann Oncol 2007, 18:581-592.

3. Hutchins LF, Unger JM, Crowley JJ, Coltman CA Jr, Albain KS: Underrepresentation of patients 65 years of age or older in cancertreatment trials. N Engl J Med 1999, 341:2061-2067.

4. Brunello A, Loaldi E, Balducci L: Dose adjustment and supportive care before and during treatment. Cancer Treat Rev 2009, 35:493-498.

5. Hurria A, Cohen HJ, Extermann M: Geriatric oncology research in the cooperative groups: A report of a SIOG special meeting. Journal of Geriatric Oncology 2010, 1:40-44.
6. Rodin MB, Mohile SG: A practical approach to geriatric assessment in oncology. J Clin Oncol 2007, 25:1936-1944.

7. Balducci L, Colloca G, Cesari M, Gambassi G: Assessment and treatment of elderly patients with cancer. Surg Oncol 2010, 19:117-123.

8. Extermann M, Hurria A: Comprehensive geriatric assessment for older patients with cancer. J Clin Oncol 2007, 25:1824-1831.

9. Extermann M, Aapro M, Bernabei R, Cohen HJ, Droz JP, Lichtman S, Mor V, Monfardini S, Repetto L, Sorbye L, Topinkova E: Use of comprehensive geriatric assessment in older cancer patients: recommendations from the task force on CGA of the International Society of Geriatric Oncology (SIOG). Crit Rev Oncol Hematol 2005, 55:241-252.

10. Overcash JA, Beckstead J, Moody L, Extermann M, Cobb S: The abbreviated comprehensive geriatric assessment (aCGA) for use in the older cancer patient as a prescreen: scoring and interpretation. Crit Rev Oncol Hematol 2006, 59:205-210.

11. Saliba D, Elliott M, Rubenstein LZ, Solomon DH, Young RT, Kamberg CJ, Roth C, MacLean CH, Shekelle PG, Sloss EM, Wenger NS: The Vulnerable Elders Survey: a tool for identifying vulnerable older people in the community. J Am Geriatr Soc 2001, 49:1691-1699.

12. Steverink N, Slaets JPJ, Schuurmans H, van Lis M: Measuring frailty: development and testing of the Groningen Frailty Indicator (GFI). The Gerontologist 2001, 41:236-237.

13. Soubeyran P, Bellera C, Goyard J, Heitz D, Cure H, Rousselot H, Albrand G, Servent V, Saint Jean O, Roy C, Mathoulin-Pelissier S, Rainfray M: Validation of the G8 screening tool in geriatric oncology: The ONCODAGE project. ASCO Annual Meeting 2011; Chicago 2011, 9001, Journal of Clinical Oncology.

14. Pallis AG, Ring A, Fortpied C, Penninckx B, Van Nes MC, Wedding U, Vonminckwitz G, Johnson CD, Wyld L, Timmer-Bonte A, Bonnetain F, Repetto L, Aapro M, Luciani A, Wildiers H: EORTC workshop on clinical trial methodology in older individuals with a diagnosis of solid tumors. Annals of oncology: official journal of the European Society for Medical Oncology/ESMO 2011, 22:1922-1926.

15. von Zglinicki T, Martin-Ruiz CM: Telomeres as biomarkers for ageing and age-related diseases. Curr Mol Med 2005, 5:197-203.

16. Bekaert S, De Meyer T, Van Oostveldt P: Telomere attrition as ageing biomarker. Anticancer Res 2005, 25:3011-3021.

17. Mather KA, Jorm AF, Parslow RA, Christensen $\mathrm{H}$ : Is telomere length a biomarker of aging? A review. J Gerontol A Biol Sci Med Sci 2011, 66:202-213.

18. Bekaert S, De Meyer T, Rietzschel ER, De Buyzere ML, De Bacquer D, Langlois M, Segers P, Cooman L, Van Damme P, Cassiman P, Van Criekinge W, Verdonck P, De Backer GG, Gillebert TC, Van Oostveldt P: Telomere length and cardiovascular risk factors in a middle-aged population free of overt cardiovascular disease. Aging Cell 2007, 6:639-647.

19. Mather KA, Jorm AF, Milburn PJ, Tan X, Easteal S, Christensen H: No associations between telomere length and age-sensitive indicators of physical function in mid and later life. J Gerontol A Biol Sci Med Sci 2010, 65:792-799.

20. Martin-Ruiz CM, Gussekloo J, van Heemst D, von Zglinicki T, Westendorp RG: Telomere length in white blood cells is not associated with morbidity or mortality in the oldest old: a population-based study. Aging Cell 2005, 4:287-290.

21. Harris SE, Deary IJ, Maclntyre A, Lamb KJ, Radhakrishnan K, Starr JM, Whalley LJ, Shiels PG: The association between telomere length, physical health, cognitive ageing, and mortality in non-demented older people. Neurosci Lett 2006, 406:260-264.

22. Murasko DM, Nelson BJ, Silver R, Matour D, Kaye D: Immunologic response in an elderly population with a mean age of 85 . Am J Med 1986, 81:612-618.

23. Sansoni P, Vescovini R, Fagnoni F, Biasini C, Zanni F, Zanlari L, Telera A, Lucchini G, Passeri G, Monti D, Franceschi C, Passeri M: The immune system in extreme longevity. Exp Gerontol 2008, 43:61-65.

24. Franceschi C, Monti D, Barbieri D, Grassilli E, Troiano L, Salvioli S, Negro P, Capri M, Guido M, Azzi R, et al: Immunosenescence in humans: deterioration or remodelling? Int Rev Immunol 1995, 12:57-74.

25. Wikby A, Maxson P, Olsson J, Johansson B, Ferguson FG: Changes in CD8 and CD4 lymphocyte subsets, T cell proliferation responses and nonsurvival in the very old: the Swedish longitudinal OCTO-immune study. Mech Ageing Dev 1998, 102:187-198. 
26. Olsson J, Wikby A, Johansson B, Lofgren S, Nilsson BO, Ferguson FG: Agerelated change in peripheral blood T-lymphocyte subpopulations and cytomegalovirus infection in the very old: the Swedish longitudinal OCTO immune study. Mech Ageing Dev 2000, 121:187-201.

27. Wikby A, Johansson B, Olsson J, Lofgren S, Nilsson BO, Ferguson F: Expansions of peripheral blood CD8 T-lymphocyte subpopulations and an association with cytomegalovirus seropositivity in the elderly: the Swedish NONA immune study. Exp Gerontol 2002, 37:445-453.

28. Given B, Sherwood PR: Family care for the older person with cancer. Semin Oncol Nurs 2006, 22:43-50.

29. Schoenmakers B, Buntinx F, De Lepeleire J: The relation between care giving and the mental health of caregivers of demented relatives: a cross-sectional study. Eur J Gen Pract 2009, 15:99-106.

30. Schoenmakers B, Buntinx F, Delepeleire J: Factors determining the impact of care-giving on caregivers of elderly patients with dementia. A systematic literature review. Maturitas 2010, 66:191-200.

31. Weinberger MI, Roth AJ, Nelson CJ: Untangling the complexities of depression diagnosis in older cancer patients. Oncologist 2009, 14:60-66.

32. Cohen M, Reuben D, Naeim A: Assessing the Older Cancer Patient. In Geriatric Oncology. Edited by: Hurria A, Balducci L. Springer US; 2009:17-45.

33. Vaes B, Pasquet A, Wallemacq P, Rezzoug N, Mekouar H, Olivier PA, Legrand D, Mathei C, Van Pottelbergh G, Degryse J: The BELFRAIL (BFC80 +) study: a population-based prospective cohort study of the very elderly in Belgium. BMC Geriatr 2010, 10:39.

34. Rivera HR: Depression symptoms in cancer caregivers. Clin J Oncol Nurs 2009, 13:195-202.

35. von Elm E, Altman DG, Egger M, Pocock SJ, Gotzsche PC Vandenbroucke JP: The Strengthening the Reporting of Observational Studies in Epidemiology (STROBE) statement: guidelines for reporting observational studies. J Clin Epidemiol 2008, 61:344-349.

36. Pallis AG, Fortpied C, Wedding U, Van Nes MC, Penninckx B, Ring A, Lacombe D, Monfardini S, Scalliet P, Wildiers H: EORTC elderly task force position paper: approach to the older cancer patient. Eur J Cancer 2010, 46:1502-1513.

37. Hurria A, Balducci L: Aging and Cancer: What Oncologists Need to Know. In Geriatric Oncology. Edited by: Hurria A, Balducci L. New York: Springer US: 2009:1-15.

38. Puts MT, Monette J, Girre V, Wolfson C, Monette M, Batist G, Bergman H: Does frailty predict hospitalization, emergency department visits, and visits to the general practitioner in older newly-diagnosed cancer patients? Results of a prospective pilot study. Crit Rev Oncol Hematol 2010, 76:142-151.

39. Minisini AM, De Faccio S, Ermacora P, Andreetta C, Fantinel R, Balestrieri M, Piga A, Puglisi F: Cognitive functions and elderly cancer patients receiving anticancer treatment: a prospective study. Crit Rev Oncol Hematol 2008, 67:71-79.

40. Marinello R, Marenco D, Roglia D, Stasi MF, Ferrando A, Ceccarelli M, Bertetto O, Molaschi M, Ciccone G: Predictors of treatment failures during chemotherapy: A prospective study on 110 older cancer patients. Arch Gerontol Geriatr 2009, 48:222-226.

41. Mahoney Fl, Barthel DW: Functional Evaluation: The Barthel Index. Md State Med J 1965, 14:61-65.

42. Collin C, Wade DT, Davies S, Horne V: The Barthel ADL Index: a reliability study. Int Disabil Stud 1988, 10:61-63.

43. Lawton MP, Brody EM: Assessment of older people: self-maintaining and instrumental activities of daily living. Gerontologist 1969, 9:179-186.

44. Yesavage JA, Brink TL, Rose TL, Lum O, Huang V, Adey M, Leirer VO: Development and validation of a geriatric depression screening scale: a preliminary report. Journal of psychiatric research 1982, 17:37-49.

45. Folstein MF, Folstein SE, McHugh PR: "Mini-mental state". A practical method for grading the cognitive state of patients for the clinician. $J$ Psychiatr Res 1975, 12:189-198.

46. De Jong-Gierveld J, Kamphuis F: The Development of a Rasch-Type Loneliness Scale. Applied Psychological Measurement 1985, 9:289-299.

47. Overcash JA, Beckstead J, Extermann M, Cobb S: The abbreviated comprehensive geriatric assessment (aCGA): a retrospective analysis. Crit Rev Oncol Hematol 2005, 54:129-136.

48. Coates A, Porzsolt F, Osoba D: Quality of life in oncology practice: prognostic value of EORTC QLQ-C30 scores in patients with advanced malignancy. Eur J Cancer 1997, 33:1025-1030.
49. Bauwens S, Baillon C, Distelmans W, Theuns P: The 'Distress Barometer': validation of method of combining the Distress Thermometer with a rated complaint scale. Psychooncology 2009, 18:534-542.

50. Sanderman R, Ormel J: De Utrechtse Coping Lijst (UCL): validiteit en betrouwbaarheid [The Utrecht Coping List (UCL): validity and precision]. Gedrag en Gezondheid 1992, 20:32-37.

51. Halfens RJ: Een gezondheidsspecifieke beheersingsorientatieschaal validiteit en betrouwbaarheid van de MHLC. T Soc Gezondheidsz 1988, 66:399-403.

52. Charlson ME, Pompei P, Ales KL, Mackenzie CR: A new method of classifying prognostic comorbidity in longitudinal studies: development and validation. J Chronic Dis 1987, 40:373-383.

53. Hughes CP, Berg L, Danziger WL, Coben LA, Martin RL: A new clinical scale for the staging of dementia. The British journal of psychiatry: the journal of mental science 1982, 140:566-572.

\section{Pre-publication history}

The pre-publication history for this paper can be accessed here: http://www.biomedcentral.com/1471-2458/11/825/prepub

doi:10.1186/1471-2458-11-825

Cite this article as: Deckx et al:: Study protocol of KLIMOP: a cohort study on the wellbeing of older cancer patients in Belgium and the Netherlands. BMC Public Health 2011 11:825.

\section{Submit your next manuscript to BioMed Central and take full advantage of:}

- Convenient online submission

- Thorough peer review

- No space constraints or color figure charges

- Immediate publication on acceptance

- Inclusion in PubMed, CAS, Scopus and Google Scholar

- Research which is freely available for redistribution

Submit your manuscript at www.biomedcentral.com/submit
Biomed Central 